\title{
Education during the COVID-19: Emergency Remote Education Ok! How About Students' and Teachers' Psychology?
}

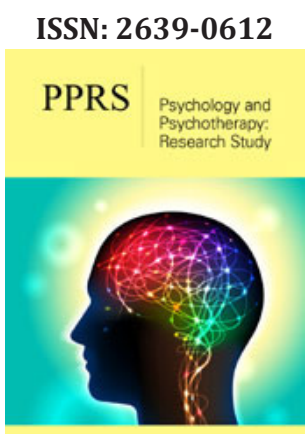

*Corresponding author: Bahadir Bahadır Eristi, Anadolu University, Turkey

Submission: 侮 May 17, 2021

Published: 眥June 09, 2021

Volume 5 - Issue 1

How to cite this article: Eristi B. Education during the COVID-19: Emergency Remote Education Ok! How About Students' and Teachers' Psychology?.Psychol Psychother Res Stud. 5(1). PPRS. 000603. 2021. DOI: 10.31031/PPRS.2021.05.000603

Copyright@ Bahadir Eristi, This article is distributed under the terms of the Creative Commons Attribution 4.0 International License, which permits unrestricted use and redistribution provided that the original author and source are credited.

\section{Bahadır Eristi*}

Anadolu University, Turkey

\begin{abstract}
There is no doubt that education is a multidimensional and highly complex process aiming at the development of human beings by using the scientific, technological, social, cultural knowledge, etc. The most basic reason that makes the educational process multidimensional and complex is that human beings show a multidimensional development in terms of many features like cognitive, psycho- social, emotion$\mathrm{al}$, and psycho-motor, etc. As every feature subject to human development is important on its own, each feature has the power to affect the development of other traits directly. Accordingly, it is an important necessity to consider human development from a holistic perspective in the education process. When the subject of human education is taken into consideration in the point of psychology, two basic dimensions come to the forefront.
\end{abstract}

\section{Mini Review}

The first of these is about the psycho-social development of students through education $[1,2]$. As it also affects behavior and personality development, this issue is important for the entire life of the individual. The second is related to the psychological foundations of learning. Most of the variables affecting learning are of psychological origin $[3,4]$. When psychological variables are ignored, it is not possible to achieve the intended results in education [5]. A teaching process that are not taken into students' motivation characteristics, attitudes, anxieties, academic self, self-esteem, etc. account cannot succeed [6]. However, schools have abandoned the duty of educating children as a whole and in all aspects, and have become a means of production directed by the markets since the industrial revolution [7]. Instead of seeing it as a human being, this distorted point of view, which sees human as an economic creature, a resource, or a human capital, does not match up with the individuality of the human being, and it is far from giving people the value they deserve. This is the most important mistake in the emergence of many contradictions that are experienced today.

It is regretful to say that, for many schools, children's individual characteristics and their development stages are important in providing clues to how much more information can be loaded on them. It is hard to say that it means more [7]. The school, which does not care enough about the responsibility of preparing students for life by developing them with their psycho-social aspects, is in an attitude as if it is very concerned about the psychological features that affect learning. This situation shows a great similarity with the viewpoints of neo-classical management theories, which consider the psychological aspects of humans as a motivational tool that only increases productivity and profitability with the classical management approach that cares about work, production, and costs instead of people.

It can be said that this distorted understanding of human education once again showed itself with the educational practices carried out during the COVID-19 pandemic. COVID-19 which was first reported in Wuhan, China in December 2019 [8], and spread rapidly and 
affected the whole world in a short time, changed life habits due to the rate of transmission and its deadly effect, as well as significant changes in the functioning of all social institutions [9]. To prevent the spread of the epidemic and to minimize loss of life, the implementation of many restrictions, including the most basic human freedoms such as traveling and going out [10] has deeply affected all sectors [11], and educational institutions [12,13] as well as rules on working life.

Schools at all levels have been closed in many countries due to restrictive measures and educational practices have been moved to online environments [14] under the name of emergency remote education [15]. Considering the spreading rate of the epidemic and the number of patients, it is necessary to say that some countries adopt hybrid or blended education practices [16]. In this period, it is possible to say that educational activities took place through interaction in virtual environments, in the form of online lessons and online exams, using the internet and digital technologies [17]. During the COVID-19 pandemic, the situation, which is expressed as a distorted understanding of education that does not prioritize humans as a value, can be explained as follows. In this process, which developed suddenly and unexpectedly with the pandemic, the implementation of emergency remote education, of course, brought along many problems that need to be solved.

When examining the aspects of the reflections of COVID-19 on education, which are the most prominent variables in the researches in the literature, it is observed that the technical discussions on the subject constitute a very important intensity. When the most prominent variables in the researches in the literature on the aspects of the reflections of COVID-19 on education are analyzed, it is observed that the technical discussions on the topic constitute a very important plurality. Accessibility to technology and the internet in online education applications, connectivity, flexibility, and ability to create learning interaction [18], academic success during the pandemic period [19], technology infrastructure competencies of schools, effectiveness of online learning process [20], technological competencies of students, teachers, and school administrators $[21,22]$, the way of having theoretical and applied lessons and exams [23], technology addiction, educational ergonomics, equality of opportunity in education [24], and teacher training during the pandemic [25] are among the topics most discussed. Based on these explanations, it can be said that the focus of the discussions during the pandemic period is the continuity of education without interruption.

It should also be noted that there are studies that address the problems teachers and students experience regarding the COVID-19 pandemic. The research focused on the cognitive [26,27], social, emotional [28], psychological [29-33], economic [34] impacts of the epidemic on students, teachers [35] and school administrators [36] could be given as examples for the aforementioned studies. Aside from the discussions about the problems caused by the pandemic, it can be said that the number of schools or countries develop solutions for the such problems arising is extremely limited. Great numbers of countries and schools only preferred to focus on teaching lessons during this difficult period by making their curriculum and instructional plans flexible instead of providing psychological support to students and teachers or contributing to their recovery.

Some issues such as teachers and students infected with the virus, the ones whose family members are sick, the experiences of teachers and students who lost their family members traumatically in this process are still unknown. The more thought-provoking aspect of the subject is that students have been tried to be educated by ignoring all these facts in this process where human psychology is massively negatively affected and anxiety of life comes to the fore, although the determining impact of psychology on learning is known clearly. In other words, pushing the psychological and emotional needs, anxieties, fears, and worries of teachers and students who have not experienced similar circumstances before into the background and considering continuing education without interruption as the most vital and prior issue in this difficult process is a dramatic situation.

It can be stated that the negative and unwilling behaviors of students, which are frequently observed in the online education process, are the most concrete reactions to educational practices in this period. Unlike the disciplinary control of the teacher in the school or classroom environment; students, who take control at their homes during the online education period, exhibited attitudes that ignore the school in response to the educational approach that did not care about themselves such as not turning on their cameras and microphones during the lesson, not participating, not taking part in the interactions, using other irrelevant applications, playing games or chatting with friends, watching videos or movies, being interested in other topics, etc. by taking advantage of their superiority over their teachers in using technology. As a result, it can be said that education continues uninterruptedly during the pandemic period. Considering the negative psychological conditions, they were in, could we say that the teachers succeed in teaching or the students were able to learn?

\section{References}

1. Durlak JA (2011) The Impact of enhancing students social and emotional wellbeing: A meta-analysis of schools based universal interventions. Child Dev 82(1): 405-432.

2. Fleming CB (2005) Do social and behavioral characteristics targeted by preventive interventions predict standardized test scores and grades? J Sch Health 75(9): 342-349.

3. Anderman EM, Anderman $1 \mathrm{H}$ (2009) Motivating children and adolescents in schools. Merrill/Prentice-Hall, OH, USA.

4. Woolfolk A (2010) Educational psychology. (11 ${ }^{\text {th }}$ edn), Pearson, London, UK.

5. Mathis BC, Cotton JW, Sechrest L (2013) Psychological Foundations of Education. Elsevier, Netherlands.

6. Treffinger DJ, Davis JK, Ripple RE (2013) Handbook on teaching educational psychology. Academic Press, New York, USA.

7. Eristi B (2018) Reasoning at school. Ankara, Pegem, Turkey.

8. WHO(2020) Novel Coronavirus (2019-nCoV) situation Report 1. 
9. Ghafoor D, Khan Z, Khan A, Ualiyeva D, Zaman N (2021) Excessive use of disinfectants against COVID-19 posing a potential threat to living beings. Curr Res Toxicol 2: 159-168.

10. Alwan NA (2020) Scientific consensus on the COVID-19 pandemic: We need to act now. The Lancet 396(10260).

11. Zhang D, Hu M, Ji Q (2020) Financial markets under the global pandemic of COVID-19. Finance Research Letters 36.

12. Karp P, McGowan M (2020) Clear as mud: Schools ask for online learning help as coronavirus policy confusion persists. The Guardian 261-307.

13. Pokhrel S, Chhetri R (2021) A literature review on Impact of COVID-19 Pandemic on teaching and learning. Higher Education for the Future 8(1): 133-141.

14. Hodges C, Moore S, Lockee B, Trust T, Bond A (2020) The difference between emergency remote teaching and online learning. Educause.

15. Bozkurt A, Sharma RC (2020) Emergency remote teaching in a time of global crisis due to Coronavirus Pandemic. Asian Journal of Distance Education 15(1): 1-6.

16. Basilaia G, Kvavadze D (2020) Transition to online education in schools during a SARS-CoV-2 Coronavirus (COVID-19) pandemic in Georgia. Pedagogical Research 5(4): 1-9.

17. Dhawan S (2020) Online learning: A panacea in the time of COVID-19 crises. Journal of Educational Technology 49(1): 5-22.

18. Aboagye E, Yawson, JA, Appiah, KN (2020) COVID-19 and E-Learning: The challenges of students in tertiary institutions. Social Education Research 2(1): 1-8.

19. Sintema EJ (2020) Effect of COVID-19 on the performance of grade 12 students: Implications for STEM education. EURASIA Journal of Mathematics, Science and Technology Education 16(7).

20. Subedi S, Nayaju S, Sweta S, Shah SK, Shah JM (2020) Impact of e-learning during COVID-19 pandemic among nurshing students and teachers of Nepal. International Journal of Science and Healthcare Research 5(3): 9.

21. Asio JMR, Bayucca SA (2021) Spearheading education during the COVID-19 rife: Administrators' level of digital competence and schools' readiness on distance learning. Journal of Pedagogical Sociology and Psychology 3(1): 19-26.

22. Klapproth F, Federkeil L, Heinschke F, Jungmann T (2020) Teachers' experiences of stress and their coping strategies during COVID-19 induced distance teaching. Journal of Pedagogical Research 4(4): 444452.

23. Mulenga EM, Marbán JM (2020) Is COVID-19 the gateway for digital learning in mathematics education? Contemporary Educational Technology 12(2).
24. Hebebci MT, Bertiz Y, Alan S (2020) Investigation of views of students and teachers on distance education practices during the Coronavirus (COVID-19) Pandemic. International Journal of Technology in Education and Science 4(4): 267-282.

25. Ferdig RE, Baumgartner E, Hartshorne R, Rakowski KR, Mouza C (2020) Teaching, technology, and teacher education during the COVID-19 Pandemic: Stories from the field. Association for the Advancement of Computing in Education (AACE).

26. Cullen W, Gulati G, Kelly BD (2020) Mental health in the COVID-19 pandemic. QJM 113(5): 311-322.

27. Urízar CA, Urzúa A, Caqueo AD, Charles CH, El-Khatib Z, et al. (2020) Mental health and the COVID-19 pandemic in Chile. Psychol Trauma 12(5): 521-523.

28. Chaturvedi K, Vishwakarma DK, Singh N (2021) COVID-19 and its impact on education, social life and mental health of students: A survey. Children and Youth Services Review (121).

29. Cao W, Fang Z, Hou G, Han M, Xu X, et al. (2020) The psychological impact of the COVID-19 epidemic on college students in China. Psychiatry Research 287: 112934.

30. Guo AA, Crum MA, Fowler LA (2021) Assessing the psychological impacts of COVID-19 in undergraduate medical students. Int J Environ Res Public Health 18(6): 2952.

31. Shah K, Kamrai D, Mekala H, Mann B, Desai K, et al. (2020) Focus on mental health during the coronavirus (COVID-19) pandemic: applying learnings from the past outbreaks. Cureus 12(3): e7405.

32. Khoury B, El-Khoury J, Ammar J (2020) Psychological needs and response during the COVID-19 pandemic in Lebanon. Psycholocig Trauma 12(5): 497-498.

33. Yassin AA, Razak NA, Saeed MA, Al-Maliki MAA, Al-Habies FA (2021) Psychological impact of the COVID-19 pandemic on local and international students in Malaysian universities. Asian Education and Development Studies.

34. Radwan A, Radwan E (2020) Social and economic impact of school closure during the outbreak of the COVID-19 pandemic: A quick online survey in the Gaza Strip. Pedagogical Research 5(4).

35. Flannery ME (2020) How teachers are integrating COVID-19 crisis into their lessons. NEA Today.

36. Francisco CDC, Nuqui AV (2020) Emergence of a situational leadership during COVID-19 pandemic called new normal leadership. International Journal of Academic Multidisciplinary Research 4 (10): 15-19. 